\title{
Luteal blood flow and progesterone secretion in pseudopregnant rabbits
}

\author{
P. O. Janson, J.-E. Damber and C. Axén \\ Department of Physiology and Obstetrics and Gynaecology, University of Göteborg, and \\ Department of Physiology, University of Umeà, Sweden
}

\begin{abstract}
Summary. Ovarian and luteal blood flow rates were measured, by means of radioactive microspheres, in anaesthetized rabbits on Day 8 of pseudopregnancy before and after lowering the ovarian perfusion pressure with a sling placed around the aorta. When blood pressure was lowered by $42 \%$ luteal flow decreased 9 -fold whilst flow to the remaining part of the ovary remained unchanged, indicating the presence of an autoregulatory mechanism in the ovarian interstitital gland.

Ovarian progesterone secretion, assessed from progesterone concentrations in ovarian venous blood, was positively correlated to the blood flow per unit of weight of luteal tissue. These data indicate that a high rate of luteal blood flow may be necessary for an optimal steroid production by the corpus luteum.
\end{abstract}

\section{Introduction}

The fully developed corpus luteum (CL) of the rabbit ovary has been shown to be associated with $80-90 \%$ of the total ovarian blood flow and the rate of flow per unit of luteal tissue weight has been reported to be extremely high (Abdul-Karim \& Bruce, 1973; Novy \& Cook, 1973; Bruce \& Hillier, 1974; Janson \& Albrecht, 1975). The functional significance of the high perfusion rate is still poorly understood. It is possible that the vascular bed of the CL contains a significant number of arteriovenous shunts (Brown, Hales \& Mattner, 1974) but if this were so then the magnitude of the total CL blood flow is of minor importance in relation to the nutrition of and hormone secretion by the CL. However, the observation that capillary luteal blood flow in the sheep is reduced 10-fold as luteolysis occurs (Bruce \& Moor, 1976) indicates that total luteal blood flow may be positively related to ovarian progesterone secretion.

The aim of the present study was to investigate the relationship between blood flow and progesterone secretion of the $C L$ of the pseudopregnant rabbit.

\section{Materials and Methods}

\section{Animals}

Altogether 13 female virgin albino Swedish Land rabbits weighing between 2.7 and $3.4 \mathrm{~kg}$ were used. They were given 100 i.u. hCG (Gonadex: Leo Ltd, Sweden) i.v. and caged individually. Injection of hCG is known to induce ovulations 10-13 h later (Harper, 1963) and pseudopregnancy lasting approximately 16 days. The size of the $C L$ increases and is maximal between Days 8 and 14. The progesterone levels in ovarian venous blood have been reported to parallel the weight curve of the CL throughout pseudopregnancy (Hilliard, Spies \& Sawyer, 1968). 


\section{Anaesthesia and surgical procedure}

On Day 8 or 9 of pseudopregnancy the rabbits were anaesthetized with pentobarbitone sodium $(30 \mathrm{mg} / \mathrm{kg}$ i.v.; Nembutal: Abbott, Kent, U.K.). They were heparinized (100 i.u. Heparin Vitrum: Vitrum, Sweden, i.v.) and placed in a supine position on a heating pad. The animals were tracheotomized and permitted to breathe air spontaneously. A polyethylene catheter (PE 90, Intramedic: Clay Adams Inc., U.S.A.) was inserted into the left ventricle of the heart via the left common carotid artery. Similar catheters were introduced into the left femoral artery for continuous recording of the blood pressure via a Statham AC Transducer connected to a Grass Model 7 Polygraph and into the right femoral artery for constant rate withdrawal of blood into a syringe, using a Harvard pump.

A low midline laparotomy was then performed and a small segment of the aorta was dissected free below the renal arteries and $1 \mathrm{~cm}$ above the origins of the ovarian arteries. A sling consisting of a PE 90 catheter was slipped around the aorta. Initially, no tension was exerted on the sling and there was no effect on aortic blood pressure and flow. The position of the catheters and aortic sling are depicted in Text-fig. 1.

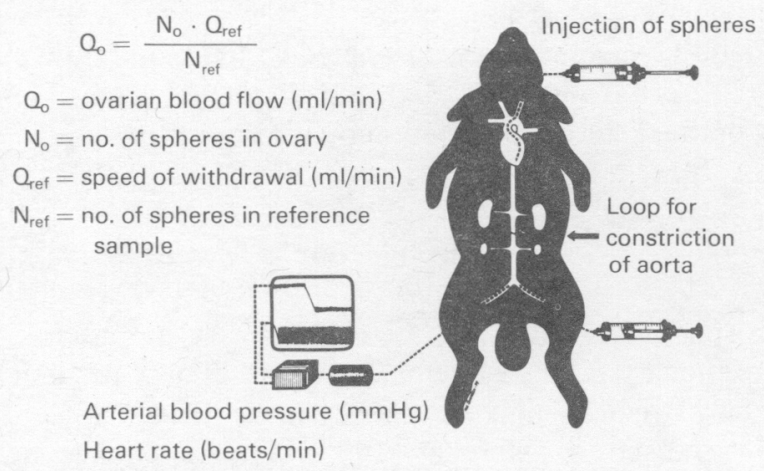

Text-fig. 1. Schematic illustration of the experimental model. The radioactive microspheres were injected into the left ventricle of the heart and blood was simultaneously withdrawn at a constant tate from the right femoral artery. The sling around the aorta was placed loosely in position before the first injection of microspheres was made.

\section{Measurements of ovarian blood flow and ovarian venous progesterone concentrations}

First measurements. When the arterial blood pressure had attained a steady level, approximately $1 \times 10^{6}$ radioactive microspheres with a diameter of $14.8 \pm 1.9 \mu \mathrm{m}$ (range) and labelled with cerium-141 ( ${ }^{141} \mathrm{Ce}$, sp. act. $9.37 \mathrm{mCi} / \mathrm{g} ; 3 \mathrm{M} \mathrm{Co}$., Minnesota, U.S.A.) were infused for $30 \mathrm{sec}$ into the left ventricle of the heart. The microspheres were suspended in 1-2 ml 0.15 $\mathrm{M}-\mathrm{NaCl}$ and were vortexed on a whirl mixer for $1 \mathrm{~min}$ before the infusion. A glass chamber was used for the mixing and infusion of spheres as described previously (Janson, 1975). From $15 \mathrm{sec}$ before, during and $15 \mathrm{sec}$ after the infusion of spheres, blood was withdrawn at a constant rate of $0.86 \mathrm{ml} / \mathrm{min}$ into a syringe to provide the reference sample. Immediately following the microsphere infusion, blood was collected into a $500 \mu \mathrm{l}$ pipette from the right ovarian vein by cutting the vessel and ligating the part leading to the inferior caval vein. Blood flow was calculated from the time taken to fill the pipette. The ovarian venous blood was then centrifuged $(1000 \mathrm{~g}$ for $10 \mathrm{~min})$ at $+4^{\circ} \mathrm{C}$ and the plasma was stored at $-80^{\circ} \mathrm{C}$ until analysis of progesterone. After collection of ovarian venous blood the right ovarian artery and vein were ligated and a blood sample from the right femoral artery was collected for analysis of progesterone.

Second measurements. In 8 rabbits which were at Day 8 of pseudopregnancy (experimental animals) the sling around the aorta was constricted $5 \mathrm{~min}$ after the first measurement. This 
resulted in a lowering of the blood pressure as measured in the left femoral artery. After adjustment of the aortic sling the lowered arterial pressure was kept at a steady level. An infusion of approximately $1 \times 10^{6}$ microspheres of diameter $17.4 \pm 0.9 \mu \mathrm{m}$ (range) and labelled with strontium-85 $\left({ }^{85} \mathrm{Sr}\right.$, sp. act. $\left.9.84 \mathrm{mCi} / \mathrm{g}\right)$ was then made into the left ventricle of the heart and blood flow measurement was carried out as described above. After the infusion of spheres blood was collected from the left ovarian vein for progesterone determination. Text-figure 2 illustrates the sequence of blood flow measurements and ovarian venous samplings.

To test whether the first injection of microspheres per se affected CL blood flow and progesterone secretion, 5 Day-9 pseudopregnant rabbits (control animals) were treated exactly as the experimental animals above except that the sling around the aorta was not constricted. (These validation trials were carried out 12 months after completion of the experiments.)

Around $5 \mathrm{~min}$ after the second measurements the animals were killed with an overdose of pentobarbitone sodium. The CL were carefully dissected from the ovaries, blotted and weighed. The remaining part of the ovary (stroma + follicles) was also blotted and weighed as well as tissue samples from the caudal parts of both kidneys. The tissues were put in separate vials for radioactivity counting in a well scintillation counter (Packard Autogamma) with channels set to cover the main energy peaks of ${ }^{141} \mathrm{Ce}$ and ${ }^{85} \mathrm{Sr}$. 'Reference' blood samples and standards containing known numbers of spheres from the actual batches were counted at the same time as the tissue samples. Blood flow values to the various tissues were calculated as described by Janson (1975).

\section{Progesterone assay}

Plasma progesterone concentrations were measured within 2 months of the experiments by a direct radioimmunoassay which was essentially the same as that described by Furyama \& Nugent (1971). The progesterone antibody was purchased from Endocrine Sciences Inc., Tarzana, California, U.S.A. and was prepared against an 11-oxime-BSA derivative. Bound and unbound steroid were separated by precipitation with saturated $\left(\mathrm{NH}_{4}\right)_{2} \mathrm{SO}_{4}$. A computer programme based on the "logit-log" method (Rodbard \& Lewald, 1970) was used for the transformation of the standard curve and for calculation of unknown samples. The sensitivity of the standard curve was $10 \mathrm{pg}$ when applying the $95 \%$ confidence limit. The mean \pm s.d. recovery for the extraction of progesterone was $89.2 \pm 8.3 \%$. Water blanks were close to zero. The concentrations of progesterone found in peripheral venous and ovarian vein plasma were in agreement with those reported by others (Hilliard, Pang, Scaramuzzi, Penardi \& Sawyer, 1974; Carlson \& Gole, 1978).

\section{Results}

\section{Experimental animals}

The intracardiac injection of microspheres caused no measurable change in arterial blood pressure and the constriction of the aortic sling depressed the blood pressure to a low and steady level (Text-fig. 2). Table 1 shows the weights of both ovaries, CL and kidneys and blood flow values of the Experimental group during the first measurements, i.e. before constriction of the aortic sling. The mean luteal weights of the right and left ovary were 36 and $40 \%$, respectively, of the total ovarian weight. The mean flows to the CL on the right and left side were 87 and $81 \%$, respectively, of the total ovarian flow. No significant difference in organ weights and relative blood flow between the right and left side were found, using Wilcoxon's paired $t$ test. Table 2 demonstrates relative blood flow to various compartments of the left ovary and to the kidneys before and after lowering the arterial blood pressure by $42 \%$. During the first measurement the mean number of microspheres trapped in the $\mathrm{CL}$ and stroma corresponded to an accuracy in the 
measurements of \pm 4 and $\pm 9 \%$, respectively (Buckberg et al., 1971). In the second measurement the accuracy was \pm 11 and $\pm 9 \%$, respectively. While there was nearly a 10 -fold reduction in luteal blood flow when lowering blood pressure, blood flows to the ovarian stroma and follicles and kidneys were virtually unchanged. The ovarian plasma concentration of progesterone was significantly reduced $(P<0.01)$ as the arterial pressure was lowered (Table 2$)$.

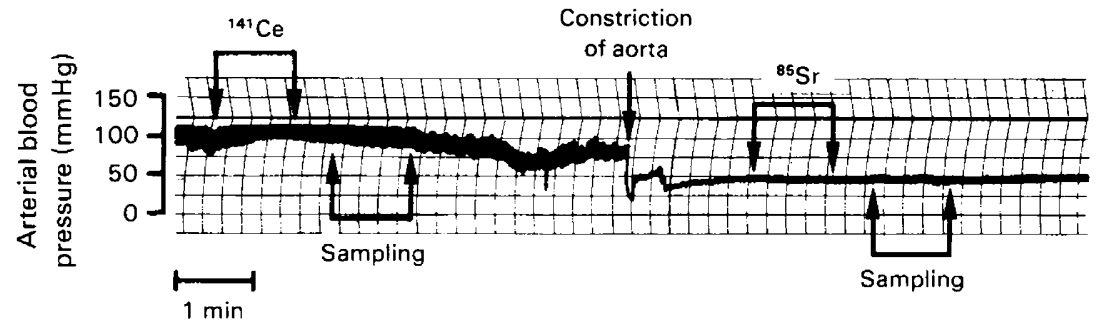

Text-fig. 2. Recording from an experiment showing the arterial blood pressure and the sequence of ovarian blood flow measurements with ${ }^{141} \mathrm{Ce}$ and ${ }^{85} \mathrm{Sr}$ microspheres, respectively, and samplings of blood from the ovarian veins.

Table 1. Blood flow to the ovaries and kidneys in 8 anaesthetized pseudopregnant rabbits

\begin{tabular}{lccccc}
\hline & \multicolumn{2}{c}{ Organ weight $(\mathrm{mg})$} & & \multicolumn{2}{c}{$\begin{array}{c}\text { Blood flow } \\
\left.\text { (ml. } \min ^{-1} .100 \mathrm{~g}^{-1}\right)\end{array}$} \\
\cline { 2 - 3 } \cline { 5 - 6 } \multicolumn{1}{c}{ Organ } & \multicolumn{1}{c}{ Right } & Left & & Right & Left \\
\hline Whole ovary & $174 \pm 26$ & $181 \pm 27$ & & $717 \pm 200$ & $761 \pm 192$ \\
Corpora lutea & $62 \pm 20$ & $72 \pm 17$ & & $1744 \pm 423$ & $1551 \pm 378$ \\
Stroma + follicles & $111 \pm 11$ & $107 \pm 14$ & & $226 \pm 63$ & $221 \pm 52$ \\
Kidneys & $-*$ & $-*$ & & $505 \pm 50$ & $473 \pm 54$ \\
\hline
\end{tabular}

Values are expressed as mean \pm s.e.m.

Measurements were performed with $14.8 \pm 1.9 \mu \mathrm{m}$ (range) microspheres labelled with ${ }^{141} \mathrm{Ce}$.

* Measurements were performed on caudal parts of each kidney (tissue weight 4-5 g).

Table 2. Ovarian and renal blood flow and ovarian venous concentrations of progesterone at two levels of arterial blood pressure in 8 anaesthetized pseudopregnant rabbits

\begin{tabular}{|c|c|c|c|c|c|c|}
\hline & \multirow{3}{*}{$\begin{array}{l}\text { Arterial blood } \\
\text { pressure } \\
(\mathrm{mmHg})\end{array}$} & \multicolumn{4}{|c|}{ Blood flow (ml. $\mathrm{min}^{-1} \cdot 100 \mathrm{~g}^{-1}$ ) } & \multirow{3}{*}{$\begin{array}{l}\text { Progesterone conc. in } \\
\text { ovarian venous } \\
\text { blood (ng/ml) }\end{array}$} \\
\hline & & \multicolumn{3}{|c|}{ Left ovary } & \multirow[b]{2}{*}{ Both kidneys } & \\
\hline & & Whole ovary & Corpora lutea & $\begin{array}{c}\text { Stroma }+ \\
\text { follicles }\end{array}$ & & \\
\hline First measurement ${ }^{\dagger}$ & $103 \pm 3$ & $761 \pm 192$ & $1551 \pm 378$ & $221 \pm 52$ & $484 \pm 49$ & $287 \pm 81 \S$ \\
\hline Second measurement $\ddagger$ & $60 \pm 4^{* *}$ & $210 \pm 40^{*}$ & $170 \pm 46^{* *}$ & $252 \pm 54$ & $457 \pm 41$ & $112 \pm 30^{* * 4}$ \\
\hline
\end{tabular}

Values are expressed as mean \pm s.e.m.

† Using ${ }^{141} \mathrm{Ce}$-labelled $14.8 \pm 1.9 \mu \mathrm{m}$ (range) microspheres.

$\ddagger$ Using ${ }^{85} \mathrm{Sr}$-labelled $17.4 \pm 0.9 \mu \mathrm{m}$ (range) microspheres.

$\S$ Right ovarian vein; peripheral plasma concentration immediately after measurement was $11.9 \pm 3.0 \mathrm{ng} / \mathrm{ml}$.

TI Left ovarian vein.

${ }^{*} P<0.05 ;{ }^{* *} P<0.01$ (Wilcoxon's paired $t$ test based on range) compared with first measurement value. 
A positive correlation between relative luteal blood flow and progesterone secretion was found ( $r=0.92, P<0.001$; Text-fig. 3).

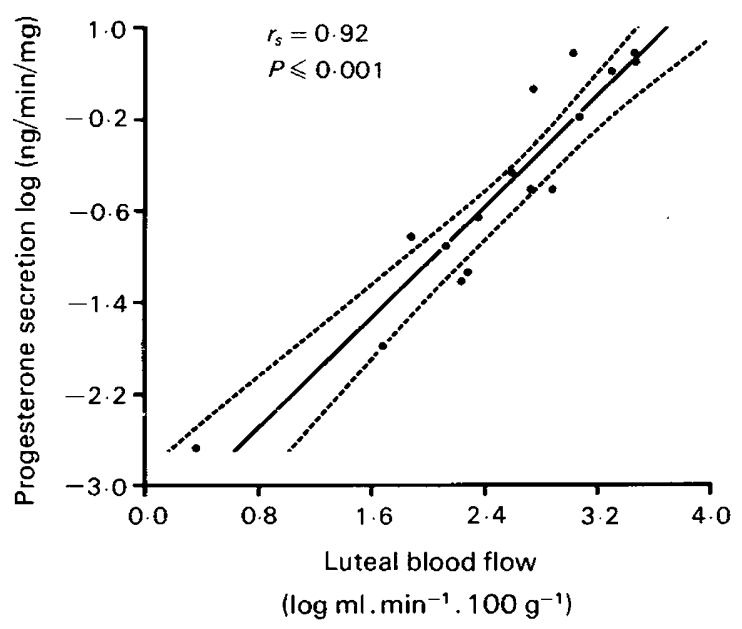

Text-fig. 3. The relationship between luteal progesterone secretion and luteal blood flow at different levels of the arterial blood pressure. Progesterone secretion per $\mathrm{mg}$ luteal tissue was calculated by multiplying the ovarian venous plasma concentration of progesterone with the ovarian venous blood flow and dividing by the haematocrit value $(41 \%$; P. O. Janson, unpublished observations) and the luteal wet weight. Two measurements were made in each of 8 rabbits. The regression line and its $95 \%$ confidence limits (broken lines) were calculated. $r_{s}$, Spearman rank correlation coefficient.

\section{Control animals}

When the aortic sling was not constricted between measurements, there was a slight but significant decrease $(P<0.05$, Wilcoxon's test for paired observations) in arterial blood pressure and blood flow to the kidneys (mean \pm s.e.m. for first measurements: $105 \pm 5 \mathrm{mmHg}$, $639 \pm 30 \mathrm{ml} \cdot \mathrm{min}^{-1} \cdot 100 \mathrm{~g}^{-1}$; second measurements: $96 \pm 5 \mathrm{mmHg}, 506 \pm 29 \mathrm{ml} \cdot \mathrm{min}^{-1} \cdot 100$ $\mathrm{g}^{-1}$ ). However, blood flow to the CL during the first measurement (range 350-1168 $\mathrm{ml} \cdot \min ^{-1} \cdot 100 \mathrm{~g}^{-1}$ ) did not differ significantly from the values at the second measurement $\left(360-932 \mathrm{ml} \cdot \mathrm{min}^{-1} \cdot 100 \mathrm{~g}^{-1}\right)$. Progesterone concentrations in the ovarian vein blood after the first injection of microspheres (range $216-344 \mathrm{ng} / \mathrm{ml}$ ) did not differ statistically from those obtained after the second injection of spheres (range $86-306 \mathrm{ng} / \mathrm{ml}$ ).

\section{Discussion}

Theoretically, the intraventricular injection of a massive dose of microspheres causes blocking of parts of the vascular bed in peripheral organs. It is reasonable to ask whether trapped microspheres in abundantly perfused tissues such as the CL caused small infarctions of functional significance. In the present study the mean number of spheres trapped in the CL after the first measurement was 2285. From the present control experiments it was evident that these spheres did not appreciably affect CL blood flow during the second injection of spheres. It was also shown that repeated injections of microspheres per se did not influence luteal progesterone secretion. This agrees with a report by Wu, Blasco, Flickinger \& Mikhail (1977) who demonstrated that three subsequent injections of microspheres did not affect ovarian steroid secretion in follicular rabbit ovaries. 
Blood leaving the ovary bearing the $\mathrm{CL}$ is the major route for the transport of progesterone from the ovary to different target organs. The present study clearly shows a positive correlation between the rate of blood flow to the $\mathrm{CL}$ and the rate of ovarian progesterone secretion. This finding is in agreement with a report by Romanoff, Deshpande \& Pincus (1962) of a positive relationship between ovarian blood flow and progesterone secretion in dogs. Similar positive relationships have been reported between adrenal (Eik-Nes, 1975) and testicular (Damber \& Janson, 1978) blood flow and steroid secretion, in dogs and rats, respectively.

The fact that ovarian venous concentration of progesterone declines in parallel with luteal blood flow may have several explanations. One reason may be that progesterone synthesis is directly dependent upon the blood flow. Flow-limited critical steps may be oxygenation, transport of steroid precursors, substrates for energy generating processes, and gonadotrophins. Another possibility is that a high blood flow rate is needed for an optimal extraction of progesterone from the CL to the blood.

The findings of the present study indicate that a high blood flow rate may be necessary for an optimal secretion of progesterone from the fully developed CL of the rabbit ovary. The fact that ovarian venous progesterone concentration declines in parallel with luteal blood flow suggests that mechanisms other than passive diffusion may regulate the transport of progesterone from the cells of the CL.

It has been postulated that luteolysis is the result of reduced blood flow to the CL due to the vasoconstrictive effect of prostaglandin F-2 $\alpha$ (Pharriss, 1970). There is, however, experimental evidence accumulating to support the view that luteolysis induced by PGF- $2 \alpha$ is not preceded by a significant reduction of arterial blood flow to the CL (Bruce \& Hillier, 1974; Janson, Albrecht \& Ahrén, 1975). In addition, studies of luteal blood flow and progesterone secretion at the time of luteal regression show that the fall in progesterone secretion precedes the decline in luteal blood flow (Hossain, Lee, Clarke \& O'Shea, 1979; Pang \& Behrman, 1979; Damber et al., 1981). However, a vascular mechanism could be of importance in the luteolytic process, probably not as a primary event but rather as a secondary one causing a rapid and efficient arrest in luteal steroid secretion.

In the present study blood flow rates in the ovarian stroma were unchanged, indicating an autoregulatory mechanism in this tissue. This finding is in accordance with the results reported by Bruce \& Gibbs (1976) who used radioactive microspheres for the measurement of ovarian blood flow in conscious pregnant rabbits. They found that ovarian blood flow was negatively related to the arterial blood pressure. The marked drop in luteal blood flow with a lowered blood pressure strongly points to a total lack of autoregulatory function in the corpus luteum which is in agreement with previous reports from this laboratory (Janson \& Albrecht, 1975).

Financial support was obtained from the Swedish Medical Research Council (projects 4982 and 5653). The technical assistance by Miss Ann-Sofie Magnusson and Mrs Agneta Nilsson is gratefully acknowledged.

\section{References}

Abdul-Karim, R.W. \& Bruce, N.W. (1973) Blood flow to the ovary and corpus luteum at different stages of gestation in the rabbit. Fert. Steril. 24, 44-47.

Bruce, N.W. \& Gibbs, C.P. (1976) Ovarian blood flow in conscious and anaesthetized pregnant rabbits near term and the influence of arterial blood gas tensions. J. Reprod. Fert. 47, 343-345.

Bruce, N.W. \& Hillier, K. (1974) The effect of prostaglandin $F_{2 \alpha}$ on ovarian blood flow and corpora lutea regression in the rabbit. Nature, Lond. 24, 176-177.
Bruce, N.W. \& Moor, R.M. (1976) Capillary blood flow to ovarian follicles, stroma and corpora lutea of anaesthetized sheep. J. Repod. Fert. 46, 299-304.

Brown, B.W., Hales, J.R.S. \& Mattner, P.E. (1974) Capillary blood flow in sheep ovaries, measured by iodoantipyrine and microsphere techniques. Experientia 30, 914-915.

Buckberg, G.D., Luck, J.C., Payne, D.B., Hoffman, J.I.E., Archie, J.P. \& Fixler, D.E. (1971) Some sources of error in measuring regional blood flow with radioactive microspheres. $J$. appl. Physiol. 31, 598-608. 
Carlson, J.C. \& Gole, J.W.D. (1978) CL regression in the pseudopregnant rabbit and the effect of treatment with prostaglandin $\mathrm{F}-2 \alpha$ and arachidonic acid. $J$. Reprod. Fert 53, 381-387.

Damber, J.-E. \& Janson, P.O. (1978) Testicular blood flow and testosterone concentrations in spermatic venous blood of anaesthetized rats. J. Reprod. Fert. 52, 265-269.

Damber, J.-E., Janson, P.O., Axén, C., Selstam, G., Cederblad, A. \& Ahrén, K. (1981) Luteal blood flow and plasma steroids in rats with corpora lutea of different ages. Acta endocr., Copenh. (in press).

Eik-Nes, K.B. (1975) Biosynthesis and secretion of testicular steroids. In Handbook of Physiology. Section 7: Endocrinology, Vol. V. Male Reproduction System, pp. 95-115. Eds D. W. Hamilton \& R. O. Greep. Am. Physiol Soc., Washington, D.C.

Furyama, S. \& Nugent, C.A. (1971) A radioimmunoassay for plasma progesterone. Steroids 17, 663674.

Harper, M.J.K. (1963) The time of ovulation in the rabbit following injection of luteinizing hormone. $J$. Endocr. 22, 147-150.

Hilliard, J., Spies, H.G. \& Sawyer, C.H. (1968) Cholesterol storage and progestin secretion during pregnancy and pseudopregnancy in the rabbit. Endocrinology 82. 157-165.

Hilliard, J., Pang, C.N., Scaramuzzi, R.J., Penardi, R \& Sawyer, C.H. (1974) Secretion rates of estradiol, testosterone and progesterone from right and left rabbit ovaries cannulated concurrently or successively. Biol. Reprod. 10, 364-369.
Hossain, M.I., Lee, C.S., Clarke, I.J. \& O'Shea, J.D. (1979) Ovarian and luteal blood flow, and peripheral plasma progesterone levels, in cyclic guinea-pigs. $J$. Reprod. Fert. 57, 167-174.

Janson, P.O. (1975) Effects of the luteinizing hormone on blood flow in the follicular rabbit ovary, as measured by radioactive microspheres. Acta endocr., Copenh. 79, 122-133.

Janson, P.O. \& Albrecht, I. (1975) Methodological aspects of blood flow measurement in ovaries containing corpora lutea. J. appl. Physiol. 38, 288-293.

Janson, P.O., Albrecht, I. \& Ahrén, K. (1975) Effects of prostaglandin $F_{2 a}$ on ovarian blood flow and vascular resistance in the pseudopregnant rabbit. Acta endocr., Copenh. 79, 337-350.

Novy, M.J. \& Cook, M.J. (1973) Redistribution of blood flow by prostaglandin $\mathrm{F}_{2 \alpha}$ in the rabbit ovary. Am.J. Obst. Gynec, 117, 381-385.

Pang, C.Y. \& Behrman, H.R. (1979) Relationship of luteal blood flow and corpus luteum function in pseudopregnant rats. Am. J. Physiol. 237, E30-34.

Pharriss, B.B. (1970) The possible vascular regulation of luteal function. Perspect. Biol. Med. 13, 434-444.

Rodbard, D. \& Lewald, J.E. (1970) Computed analysis of radio-ligand assay and radioimmunoassay data. Acta endocr., Copenh., Suppl. 147, 79-98.

Romanoff, E.B., Deshpande, N. \& Pincus, G. (1962) Rate of ovarian progesterone secretion in the dog. Endocrinology 70, 532-539.

Wu, C.H., Blasco, L., Flickinger, G.L. \& Mikhail, G. (1977) Ovarian function in the preovulatory rabbit. Biol. Reprod. 17, 304-308. 